\title{
Peningkatan Kompetensi Masyarakat di Kampung Yoboi Kabupaten Jayapura dalam Budidaya Jamur dan Pengolahan Makanan Berbahan Jamur
}

\author{
Supeni Sufaati*1, Verena Agustini ${ }^{1}$ dan Yokelin Tokoro ${ }^{2}$ \\ ${ }^{1}$ Program Studi Biologi FMIPA Universitas Cenderawasih Jayapura \\ ${ }^{2}$ Program Studi Sistim Informasi FMIPA Universitas Cenderawasih Jayapura \\ *Alamat korespondensi : penisufaati@gmail.com
}

\begin{abstract}
ABSTRAK
Masyarakat Kampung Yoboi, Kabupaten Jayapura memanfaatkan tepung sagu dan jamur sagu sebagai makanannya. Limbah ampas sagu merupakan media tumbuh bagi jamur. Kegiatan ini dilaksanakan dengan tujuan untuk meningkatkan pengetahuan masyarakat tentang kandungan gizi jamur, cara budidaya jamur dan membuat berbagai makanan berbahan dasar jamur. Metode yang digunakan adalah Focus Group Discussion (FGD) dan Participatory Planning. Hasil kegiatan ini menunjukkan bahwa para peserta sangat antusias dalam diskusi tentang kandungan gizi jamur dan juga sangat aktif mengikuti praktek budidaya jamur serta memasak makanan berbahan dasar jamur. Kegiatan ini telah sukses dilaksanakan berkat partisipasi aktif dari seluruh masyarakat.
\end{abstract}

Kata Kunci: Kampung Yoboi, ampas sagu, budidaya jamur, pemberdayaan masyarakat

ABSTRACT

The Yoboi community utilize sago starch and sago mushrooms as their food. Sago pulp waste is a growing medium for mushrooms. The purpose of this community service was to enlighten the local people on the mushroom nutrient content, to empower community on mushrooms cultivation using sago waste, and to produce various food from mushroom. The methods that use in this program were Focus Group Discussion (FGD) and Participatory Planning in this program. The results of this activity showed that the participants were very enthusiastic in the discussion and were also very active in practicing mushroom cultivation and cooking mushroom-based foods. This activity were successfully done with the support by communities.

Keywords: Yoboi Village, sago waste, mushroom cultivation, community empowerment

\section{PENDAHULUAN}

Salah satu perkampungan tua yang ada di pulau-pulau di danau Sentani, Kabupaten Jayapura, Provinsi Papua adalah Kampung Yoboi. Kampung ini memiliki potensi alam yang berlimpah antara lain berupa hutan sagu, ikan dari danau Sentani, kebun keladi dan lain sebagainya. Sebagian besar penduduknya menggantungkan hidup dari hasil tangkapan danau Sentani dan hutan sagu. Hutan sagu memiliki peran yang sangat penting baik secara ekonomi maupun etnobotani dan juga ekologi. Hutan sagu merupakan sumber penghasilan bagi masyarakat kampung Yoboi. Hasil olahan sagu merupakan makanan pokok bagi masyarakat di sana. Sagu diolah menjadi papeda, sagu bakar, dan olahan sagu lainnya. Selain dimakan sebagai menu harian, papeda juga merupakan makanan yang wajib untuk disajikan dalam hidangan pesta adat bersama dengan ikan gabus Sentani.

Ibu-ibu di kampung ini banyak yang berprofesi sebagai pengolah sagu atau yang dalam istilah lokal disebut sebagai "penokok sagu". Menotok sagu merupakan bagian yang sangat penting untuk 
mendapatkan sagu. Pohon sagu yang telah tua, ditebang dan dipotong menjadi beberapa potong oleh para bapak. Selanjutnya batang sagu tersebut dibelah menjadi dua. Bagian dalam dari batang sagu kemudian dihancurkan dengan alat semacam kapak atau "ditokok". Untuk mendapatkan sagunya, hasil tokok sagu tersebut dicampur dengan air dan diremas-remas lalu diperas. Air perasan sagu kemudian disaring dan ditampung dalam suatu wadah lalu diendapkan. Endapan pati sagu itulah yang selanjutnya akan diolah menjadi tepung sagu. Sedangkan ampas sagunya dibuang begitu saja di sekitar lokasi pengolahan sagu.

Tempat buangan limbah sagu (ampas sagu) dan air buangan dari hasil perasan sagu dapat menjadi lahan subur yang menghasilkan jamur sagu. Lahan bekas olahan sagu yang sudah lebih dari 1 bulan, dengan kondisi ampas sagu sudah membusuk, akan menjadi lahan subur tumbuhnya jamur sagu. Jamur sagu ini tidak dapat tumbuh di sembarangan tempat, namun menurut pengamatan warga, jamur sagu ini hanya dapat tumbuh di tempat/lahan yang mengandung pati/sari dari pohon sagu.

Selain menjadi habitat bagi jamur sagu, ampas sagu yang mengandung selulosa dan lignin juga dapat dimanfaatkan sebagai media untuk menumbuhkan jamur tiram putih. Namun sayangnya selama ini limbah tersebut tidak dimanfaatkan secara maksimal. Hal ini karena masyarakat belum mengetahui cara budidaya jamur tiram putih. Padahal kampung ini memiliki potensi untuk budidaya jamur karena media tumbuh berupa limbah sagu tersedia melimpah. Oleh karena itu, perlu dikenalkan teknologi sederhana untuk memanfaatkan limbah sagu sebagai media budidaya jamur seperti jamur tiram putih bagi masyarakat di Kampung Yoboi.

Pada saat dilakukan wawancara dengan beberapa ibu-ibu diketahui bahwa sebagian besar mereka mengenal dan pernah memasak serta mengkonsumsi jamur sagu. Menurut mereka, jamur sagu rasanya enak. Namun kandungan gizi jamur khususnya jamur sagu dan manfaatnya bagi kesehatan masih belum dipahami oleh masyarakat. Selain itu, selama ini masyarakat memanfaatkan jamur sagu yang tumbuh secara alami di sekitar hutan sagu untuk dikonsumsi sendiri. Jika panennya berlebihan terutama pada musim hujan maka mereka menjual jamur sagu segar ke pasar. Padahal jika jamur tersebut diolah menjadi makanan atau camilan yang menarik maka dapat meningkatkan nilai jualnya. Dengan demikian dirasa perlu untuk memberikan pelatihan mengenai pengolahan makanan berbahan dasar jamur termasuk jamur sagu untuk menambah gizi dan juga pendapatan keluarga dan masyarakat Kampung Yoboi.

\section{BAHAN DAN METODE}

Metode yang digunakan dalam mendukung penyelesaian masalah ini adalah:

1. Metode Focus Group Discussion (FGD)

Metode ini digunakan untuk memetakan pengetahuan masyarakat tentang kandungan gizi jamur dan manfaatnya bagi kesehatan, serta cara budidaya jamur tiram putih dengan teknologi tepat guna yang sederhana. 


\section{Metode Perencanaan Partisipatif}

Perencanaan partisipatif dilakukan untuk mengikutsertakan masyarakat dalam pelatihan budidaya jamur tiram putih dengan teknologi tepat guna yang sederhana dan pengolahan makanan berbahan dasar jamur sagu dan jamur tiram putih

3. Metode Praktek

Melakukan praktek cara budidaya jamur tiram putih dengan teknologi tepat guna yang sederhana dan memasak makanan berbahan dasar jamur sagu dan jamur tiram putih.

Adapun kegiatan yang dilakukan dan luaran yang dihasilkan tercantum dalam tabel berikut :

\begin{tabular}{|c|c|c|c|}
\hline No & Kegiatan & Partisipasi masyarakat & Luaran \\
\hline & Sosialisasi kegiatan & $\begin{array}{l}\text { Sebagai peserta } \\
\text { sosialisasi }\end{array}$ & $\begin{array}{l}15 \text { anggota masyarakat memahami } \\
\text { dan menyetujui tujuan kegiatan }\end{array}$ \\
\hline & $\begin{array}{l}\text { Diskusi tentang kandungan } \\
\text { gizi jamur sagu dan jamur } \\
\text { tiram putih serta } \\
\text { manfaatnya bagi kesehatan. }\end{array}$ & Menentukan peserta & $\begin{array}{l}15 \text { anggota masyarakat memahami } \\
\text { kandungan gizi jamur sagu dan } \\
\text { jamur tiram putih serta manfaatnya } \\
\text { bagi kesehatan. }\end{array}$ \\
\hline & $\begin{array}{l}\text { Pelatihan tentang cara } \\
\text { budidaya jamur tiram putih } \\
\text { dengan teknologi tepat guna } \\
\text { yang sederhana }\end{array}$ & $\begin{array}{l}\text { Berperan aktif dalam } \\
\text { pelatihan }\end{array}$ & $\begin{array}{l}15 \text { anggota masyarakat memahami } \\
\text { tentang cara budidaya jamur tiram } \\
\text { putih dengan teknologi tepat guna } \\
\text { yang sederhana }\end{array}$ \\
\hline & $\begin{array}{l}\text { Pelatihan tentang cara } \\
\text { memasak jamur sagu dan } \\
\text { jamur tiram putih }\end{array}$ & $\begin{array}{l}\text { Berperan aktif dalam } \\
\text { pelatihan }\end{array}$ & $\begin{array}{l}15 \text { anggota masyarakat memahami } \\
\text { tentang cara memasak jamur sagu } \\
\text { dan jamur tiram putih }\end{array}$ \\
\hline
\end{tabular}

\section{HASIL}

Untuk lebih memberikan gambaran tentang budidaya jamur, maka para ibu PKK Kampung Yoboi diundang berkunjung ke Unit Usaha Budidaya Jamur di Jurusan Biologi FMIPA Uncen yang telah membudidayakan jamur tiram putih selama 3 tahun dalam program PPUPIK. Pada kunjungan tersebut, sebanyak 15 orang perwakilan anggota PKK Kampung Yoboi mengikuti pelatihan budidaya jamur dan sekaligus pengolahan pasca panen jamur hingga penyajiannya.

Kegiatan dimulai dengan diskusi mengenai pemahaman awal peserta mengenai jamur dan pengenalan teori sederhana tentang kandungan gizi jamur sagu dan jamur tiram, serta penjelasan singkat tentang budidaya jamur jamur tiram. Setelah itu dilanjutkan dengan praktek cara budidaya jamur tiram dari pembuatan media, sterilisasi, inokulasi, inkubasi, perawatan di kumbung jamur, hingga panen jamur. Selain cara budidaya, peserta juga diberikan pengetahuan dan keterampilan mengenai cara pengolahan 
aneka masakan dari jamur sagu dan jamur tiram seperti sate jamur, krispi jamur, dan bakwan jamur. Yang tid

ak kalah penting juga penyajian, pengemasan dan penampilan hasil masakan bila nantinya akan dijadikan bisnis kuliner juga diajarkan dalam pelatihan ini. Para peserta sangat antusias dalam mengikuti seluruh rangkaian kegiatan dari awal hingga akhir.

\section{PEMBAHASAN}

Dari hasil diskusi dengan para peserta kegiatan ini diketahui bahwa masyarakat sangat mengenal jamur sagu di alam. Jamur sagu diambil dari lahan bekas olahan sagu yang sudah dibiarkan. Jamur ini adalah salah satu jamur yang umum dikonsumsi oleh masyarakat di Papua, khususnya di daerah yang banyak terdapat hutan sagu. Jamur yang bentuknya mirip dengan jamur merang ini dikenal dengan nama latin Volvariella sp dan banyak terdapat di hutan sagu di dataran rendah Papua. Pertumbuhan jamur ini ditentukan oleh kondisi habitatnya (Abbas, dkk, 2011, Paisey and Abbas, 2015).

Sebagian jamur sagu yang dipanen dimanfaatkan langsung untuk dimasak. Penduduk kampung Yoboi sangat menyukai jamur sagu sebagai bahan untuk dimasak dalam menu sehari hari bagi keluarga. Para ibu biasanya mengolah jamur sagu dengan cara ditumis atau direbus untuk disajikan dengan papeda yaitu makanan khas Papua yang dibuat dari tepung sagu. Sebagaimana jamur pangan liar lain yang berperan penting sebagai sumber bahan pangan bagi masyarakat di pedalaman Papua (Yigibalom, dkk., 2014), maka jamur sagu juga dapat dimanfaatkan untuk meningkatkan gizi masyarakat. Jamur sagu memiliki nilai gizi yang tinggi terutama protein, selain itu juga terdapat karbohidrat, namun kadar lemaknya rendah sehingga baik untuk kesehatan tubuh (Purnamasari dan Sufaati, 2014; Paisey and Abbas, 2015).

Jika hasil panen jamur sagu berlebihan maka selain dikonsumsi sendiri, sebagian lagi dibawa ke pasar untuk dijual untuk menambah penghasilan keluarga dan memenuhi kebutuhan sehari-hari. Harga jual jamur sagu di pasar yaitu Rp. 30.000,- per tumpuk (300-400 gr per tumpuk) atau sekitar Rp. 90.000,sampai Rp. 100.000,- per kilo. Harga jamur sagu lebih tinggi jika dibandingkan dengan harga jamur tiram putih di Jayapura yaitu sekitar Rp 75.000,- per kilo (Agustini dkk ,2017). Dalam satu hari, seorang pedagang jamur bisa menjual 10-15 tumpuk sehingga bisa memperoleh pendapatan kotor Rp. 300.000,hingga Rp.450.000,-. Penghasilan ini cukup tinggi sehingga dengan berjualan jamur sagu dapat meningkatkan pendapatan masyarakat di sekitar hutan sagu. Bahkan di abad ke 21 ini budidaya jamur dan produk turunannya memberikan pengaruh yang sangat besar bagi kesejahteraan manusia sehingga dikenal dengan istilah"Non-green revolution" (Chang and Miles, 2004).

Pada saat praktek budidaya jamur tiram putih, para peserta yang baru pertama kali mengikuti pelatihan budidaya jamur cukup paham dan sangat aktif ikut membuat media, menginokulasi bibit ke dalam baglog, hingga panen jamur di kumbung. Hal ini karena budidaya jamur tiram di Unit Usaha Budidaya Jamur Jurusan Biologi Uncen dilakukan dengan cara dan metode yang sederhana dan 
menggunakan bahan limbah yang tersedia di lingkungan yaitu serbuk gergaji (Agustini, 2017). Selain serbuk gergaji, bahan lain yang ada di sekitar Jayapura seperti ampas sagu juga bisa dimanfaatkan sebagai media budidaya jamur tiram.

Selama mengikuti pelatihan ini, para ibu PKK Kampung Yoboi merasakan manfaatnya yaitu berupa peningkatan pengetahuan dan keterampilan tentang cara budidaya jamur tiram putih dan pengolahan makanan berbahan dasar jamur sagu dan jamur tiram putih. Mereka berminat untuk mengolah jamur sagu menjadi makanan yang bentuknya menarik dan variatif seperti sate jamur dan jamur krispi sehingga anggota keluarga dan masyarakat umum akan lebih menyukai untuk mengkonsumsi jamur sagu. Dengan demikian maka nilai jual jamur sagu menjadi bertambah sekaligus juga dapat meningkatkan penghasilan keluarga.

Pada saat ini bisnis kuliner di Jayapura berkembang sangat pesat, sehingga potensi untuk mengembangkan varian makanan dari jamur masih terbuka lebar (Agustini dkk, 2018). Outcome dari kegiatan ini diharapkan akan ada peserta yang tertarik untuk lebih serius dalam membudidayakan jamur tiram putih dan membuat makanan berbahan dasar jamur. Melalui pelatihan budidaya jamur dan pengolahan pasca panennya dapat meningkatkan kompetensi anggota masyarakat, sehingga akan lahir wirausaha baru yang menekuni bisnis jamur dan olahannya (Agustini dkk, 2017 dan Agustini dkk, 2018). Dalam jangka panjang, jika kompetensi masyarakat meningkat maka kesejahteraan masyarakat juga akan meningkat pula.

\section{KESIMPULAN DAN SARAN}

Dari kegiatan ini dapat disimpulkan bahwa masyarakat sangat antusias untuk mengetahui kandungan gizi jamur sagu dan jamur tiram, cara budidaya jamur tiram dan cara memasak jamur dengan berbagai variasi yang disukai oleh anak-anak dan masyarakat luas. Kegiatan ini bisa dilanjutkan dengan melibatkan komponen masyarakat yang lebih luas di kampung lain di Jayapura.

\section{UCAPAN TERIMA KASIH}

Penerapan IPTEKS ini dibiayai dari PNBP LPPM UNCEN Tahun 2018 dengan No Kontrak: 036/UN.20.2.2/PNBP/PM/2018 tanggal 23 April 2018. Terimakasih juga disampaikan kepada Kepala Kampung dan masyarakat Yoboi yang telah mendukung kegiatan ini.

\section{DAFTAR PUSTAKA}

Abbas, B., Florentina Heningtyas Listyorini, dan Eko Agus Martanto, 2011, Karakteristik Jamur Sagu (Volvariella sp.) Endemik Papua, Jurnal Natur Indonesia 13(2): 168-173.

Agustini, V , Supeni Sufaati, Yuliana Waromi, Dirk Y.P. Runtuboi, 2017, Usaha IbIKK Jamur Tiram Jurnal Pengabdian Pada Masyarakat UNJA, 31(4) 
Agustini, V , Supeni Sufaati, Bonifasia Elita Bharanti, Dirk Y.P. Runtuboi, 2018, Budidaya Jamur Tiram Putih (Pleurotus ostreatus) sebagai Percontohan dan Unit Usaha Budidaya Jamur (UUBJ) di Universitas Cenderawasih, J. Pengabdian Masyarakat MIPA dan Pendidikan MIPA UNY, 2 (1), 28-32

Chang, Shu-Ting and Philip G. Miles. 2004. Mushrooms : Cultivation, Nutritional Value, Medicinal Effect, and Environmental Impact, $2^{\text {nd }}$ Edition. CRC Press. New York

Paisey, E., C. and Barahima Abbas, 2015, Morphological Characteristics and Nutritional Values of Wild Types of Sago Mushrooms (Volvariella sp.) That Growth Naturally in Manokwari, West Papua, Natural Science, 7 (13): 599-604

Purnamasari, V dan S. Sufaati, 2014. Nilai kimia jamur sagu. Poster dipresentasikan pada Seminar Pokjanas Jamindo, Bogor.

Yigibalom, S., S. Sufaati dan V. Purnamasari, 2014, Analisa Kadar Protein Jamur Alam yang Dominan dikonsumsi Masyarakat Lokal di Kabupaten Lanny Jaya, Jurnal Biologi Papua, 6 (2): 75-79 


\section{LAMPIRAN}

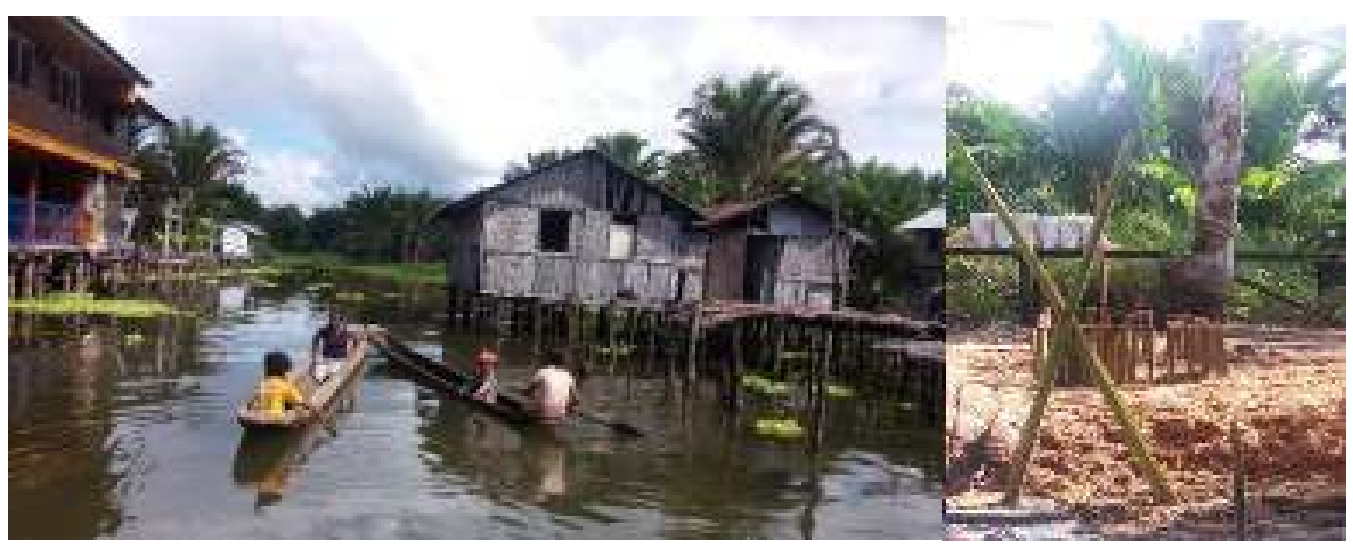

Gambar 1. Aktivitas masyarakat di Kampung Yoboi (kiri) dan lokasi pengolahan sagu (kanan).

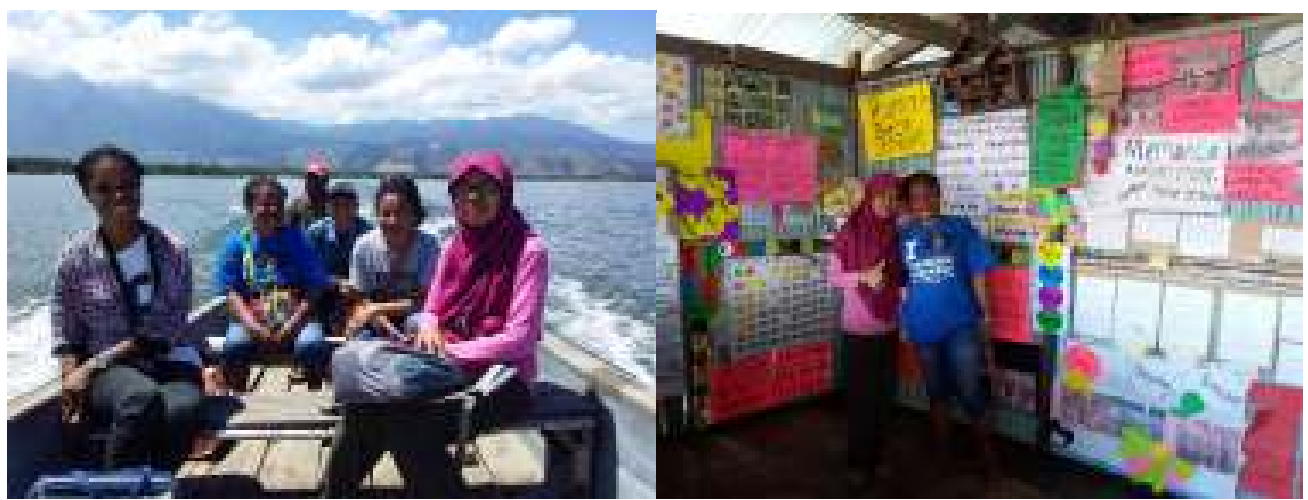

Gambar 2. Transportasi menuju Kampung Yoboi (kiri) dan salah satu rumah warga Yoboi 


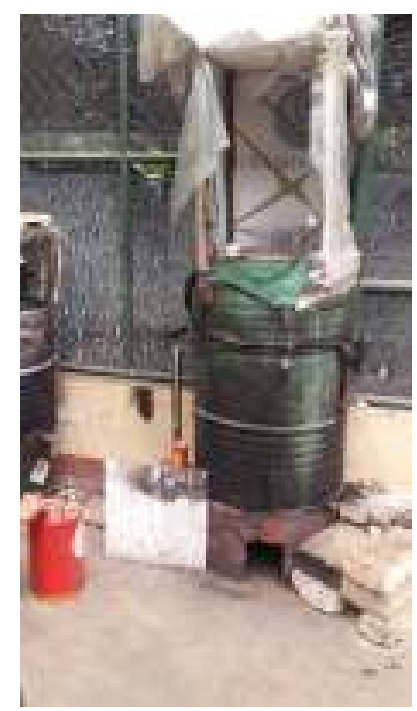

Gambar 3. Alat sterilisasi media jamur

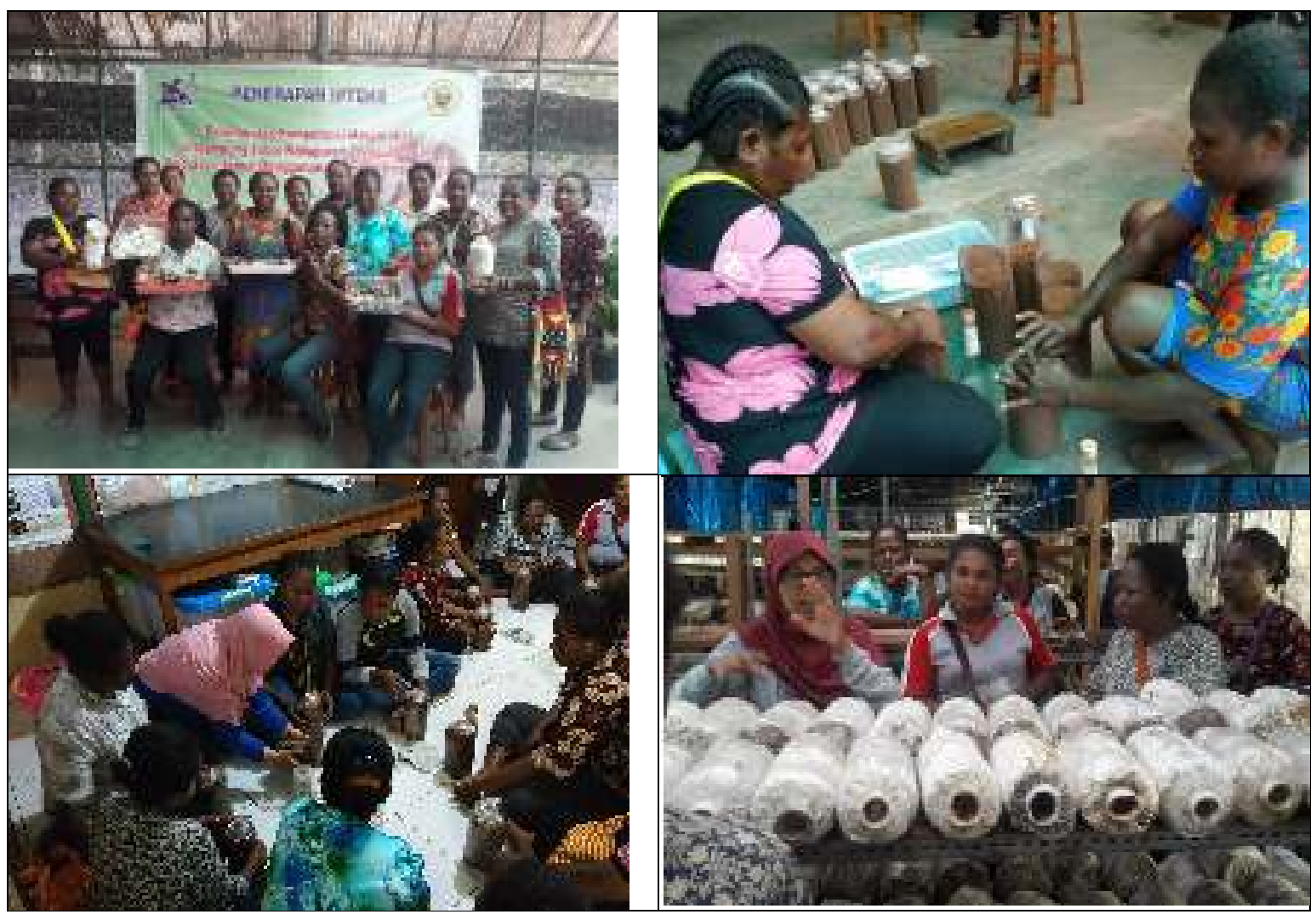

Gambar 4. Peserta tekun mengikuti pelatihan cara budidaya jamur putih 
Peningkatan Kompetensi Masyarakat di Kampung Yoboi Kabupaten Jayapura dalam Budidaya Jamur dan Pengolahan Makanan Berbahan Jamur

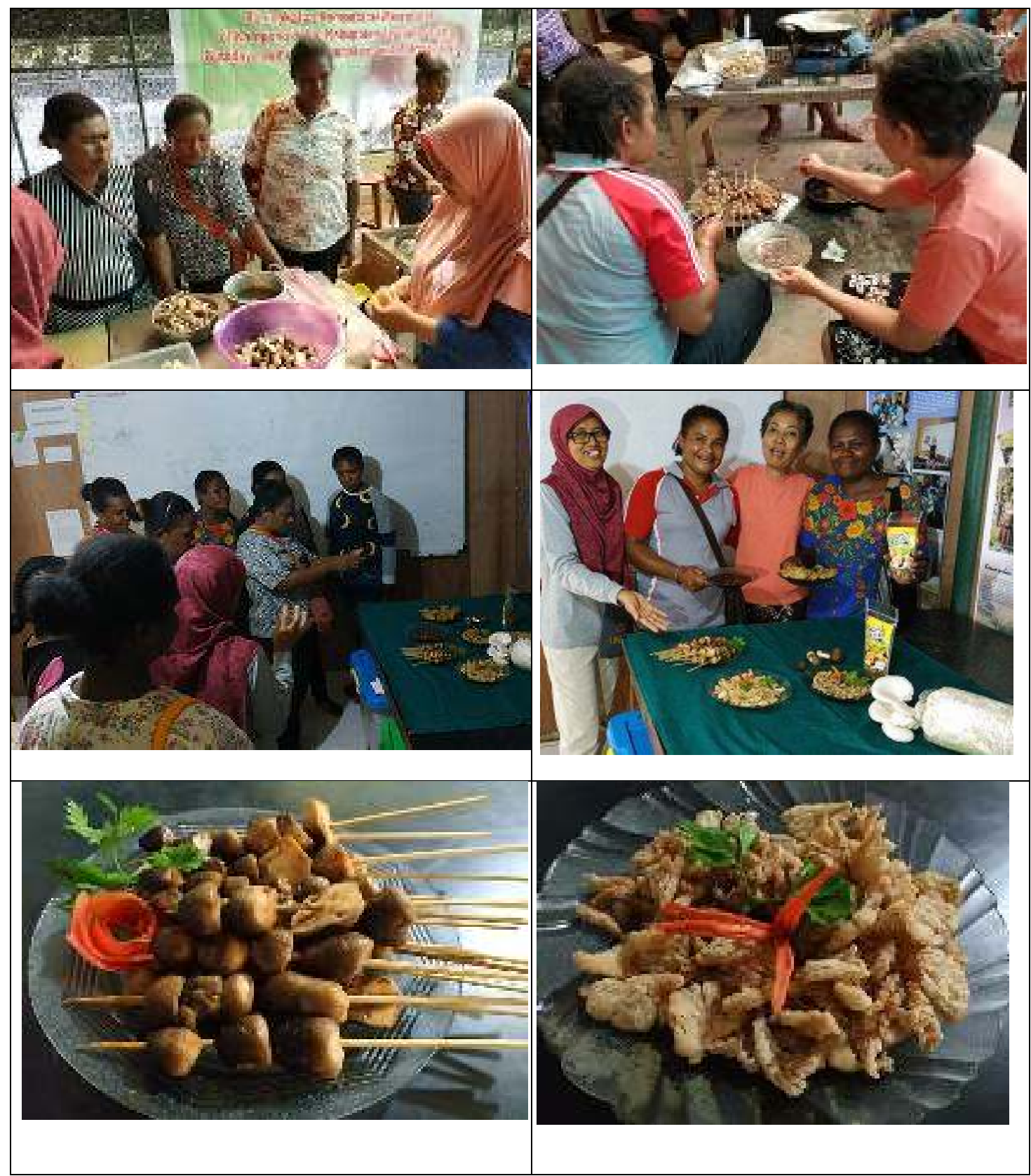

Gambar 5. Praktek memasak dan menyajikan olahan sate jamur sagu dan krispi jamur tiram 